\title{
Comparison of methods for stock assessment of European hake Merluccius merluccius in the Gulf of Lions (Northwestern Mediterranean)
}

\author{
Yvonne Aldebert ${ }^{(1)}$ and Laura Recasens \\ (2) \\ (1) IFREMER, 1, rue Jean-Vilar, 34200 Sète, France. \\ (2) CSIC-ICM, P. Joan de Borbó s/n, 08039 Barcelona, Espagne.
}

Received December 16, 1994; accepted July 3, 1995.

Aldebert Y., L. Recasens. Aquat. Living Resour., 1996, 9, 13-22.

\begin{abstract}
European hake Merluccius merluccius is the main commercial demersal species in the Gulf of Lions (Northwestern Mediterranean). This fish is exploited by French and Spanish trawler fleets and by smallscale fisheries using gillnets and longlines. Data on landings and the demography of catches by type of gear are now available for the period 1988-1991. The assessment of the hake stock was carried out using methods of virtual population analysis (VPA), or cohort analysis, based respectively on mean pseudocohorts and cohorts by age. The results of these VPA were then analysed and compared from a methodological point of view. The general results have confirmed previous studies with regard to the level of exploitation of the species. The two methods gave quite similar results for fishing mortality rates and for mean biomass. The maximal fishing mortality rate was observed at age 4 , but it was already high at age 1 , due to the exploitation of juveniles by trawlers. The mean biomass was about 7000 tons. The high values for turnover (about $80 \%$ or more) and for the maximal biomass/mean biomass ratio (23\% or more) indicated a high level of exploitation but did not seem high enough to be dangerous for the stock. Yield-per-recruit analysis showed also that the present level of exploitation is far above the optimal sustainable level.
\end{abstract}

Keywords: Merluccius merluccius, Mediterranean Sea, methodology, stock assessment, population structure, fishing mortality.

Comparaison de deux méthodes pour l'évaluation du stock de merlu Merluccius merluccius dans le golfe du Lion.

Résumé

Le merlu Merluccius merluccius est l'espèce démersale la plus importante du golfe du Lion (Méditerranée nord-occidentale). Il est exploité intensivement par deux flottilles chalutières française et espagnole ainsi que par deux types de métiers artisanaux, filets maillants et palangres de fond. Des données portant sur les quantités débarquées et la démographie des captures étant disponibles pour la période 1988-1991, l'évaluation du stock a été réalisée selon deux méthodes d'analyse des populations virtuelles (VPA), basées respectivement sur l'analyse des pseudo-cohortes et des cohortes d'âge vraies. Les résultats de ces VPA ont ensuite été analysés et comparés d'un point de vue méthodologique. Les deux méthodes ont conduit à des estimations assez proches pour la biomasse moyenne et les taux de mortalité par pêche $\mathrm{F}$. En raison d'une exploitation des juvéniles par les chalutiers, la mortalité par pêche est importante dès la première année de vie, le maximum étant atteint pour le groupe d'âge 4. Pour la période 1988-1991, la biomasse moyenne de merlu dans le golfe du Lion était d'environ 7000 tonnes. Globalement, les résultats confirment ceux des études antérieures quant au degré d'exploitation du stock de merlu. Les valeurs élevées du " turnover " ( $80 \%$ environ ou plus) et du rapport biomasse maximale/biomasse moyenne ( $23 \%$ ou plus) sont significatives d'une pêche intensive du merlu, ce qui est confirmé par l'analyse du rendement par recrue qui situe l'optimum bien en-deça du niveau actuel d'exploitation.

Mots-clés : Merluccius merluccius, Méditerranée, méthodologie, évaluation des stocks, démographie des captures, mortalité par pêche. 


\section{INTRODUCTION}

From a commercial point of view, European hake Merluccius merluccius (L.) is the most important species for demersal fisheries in the Gulf of Lions. The stock is exploited mainly by a large French trawler fleet and a smaller Spanish trawler flect, and also by small-scale fleets using steady gear, i.e. gillnets used by French fishermen and longlines by Spanish fishermen. Fishing grounds and patterns of exploitation were previously described by Aldebert et al. (1993). The two trawler fleets catch fish of all sizes but mostly small immature individuals, whereas gillnets and longlines only catch fish larger than thirty centimetres with a majority of adults.

Several studies on the stock and on biology of hake have been carried out over the past few years. The first studies on population dynamics dealt with exploitation of hake stock by French or Spanish fleets separately (Aldebert and Carries, 1988; Recasens, $1992 a, b)$. More recently, the results of a study based on total landings of hake in the two countries in 1988 were published (Aldebert et al., 1993). This study consisted mainly of a virtual population analysis (VPA) based on length pseudocohorts for two sets of different biological parameters. The impact of each type of gear on catches and on yield-per-recruit (Y/R) was also estimated according to variations in fishing mortality vectors. The main software used for these analyses was VIT (Lleonart and Salat, 1992).

Now that data is available for a period of four years (1988-1991), it seems useful to resume and develop the study of hake dynamics in the area. Even if such a period is not very long, a first attempt to perform a classical cohort analysis can be undertaken. This should allow comparison of the results of VPA using real cohorts and pseudocohorts for stock assessment and fishing mortality rates. Furthermore, this new assessment should give more accurate estimations of the stock of hake in the Gulf of Lions and its interannual fluctuations.

With this aim in view, we have used two computer programs. One of them, ANACO, (Mesnil, 1989) performs a standard virtual population analysis on age data and requires the availability of several years' information. In the Mediterranean, this program has already been used for other species such as the red shrimp (Demestre and Lleonart, 1993). The VPA carried out by the other software, VIT, is based on pseudocohort analysis. In most cases there is no routine sampling of landlings in Mediterranean countries and thus no historical series of data. Consequently, this type of analysis has to be applied to the Mediterranean exploited marine populations. It is the case for various species in the area such as hake and red mullet (Oliver, 1993), sardine (Pertiera and Perrota, 1993), sole, sea bream and sea bass (Farrugio et al., 1994), and also red shrimp (Demestre and Lleonart, 1993).

\section{MATERIAL AND METHODS}

\section{Methods}

Both ANACO and VIT are computer programs performing the Virtual Population Analysis (VPA), or cohort analysis, widely used in the stock assessment of exploited marine resources based on catch data. The basic equations of the VPA (Gulland, 1983) are the survival equation:

$$
N_{i+1}=N_{i} \cdot e^{-Z_{i} \cdot \Delta t_{2}}
$$

and the catch equation:

$$
C_{i}=F_{i} \cdot N_{i}\left(1-e^{-Z_{i} \cdot \Delta t_{2}}\right) / Z_{i}
$$

where $C_{i}=$ catch in time period $i$,

$$
\Delta t_{i}=t_{i+1}-t_{i},
$$

$N_{i}=$ stock size at the beginning of the time period $i$,

$Z_{i}=$ total mortality rate in time period $i$, and $Z_{i}=F_{i}+M_{i}$,

where $F_{i}=$ fishing mortality rate in time period $i$,

and $M_{i}=$ natural mortality rate in time period $i$.

As previously said, ANACO performs standard VPA based on catch data structured by age and needs a long series of data (at least a complete cohort) with no missing period to be used on optimal conditions. As well as other programs based on pseudocohorts, VIT works on the equilibrium assumption of constant recruitment and mortality and of constant level of exploitation. VIT allows the VPA to be performed using catch data structured by age or size; it requires only one year data. For the present study age pseudocohorts were used in order to allow direct comparisons with $\mathrm{ANACO}$ results. The main requirements and the VPA output of the two programs are summarized in table 1. Both softwares also allow analysis of data from different gear and determination of the fishing mortality rate corresponding to each gear, using the equation:

$$
F_{i, j, y}=F_{i, y} \cdot C_{i, j, y} / C_{i, y}
$$

were $C_{i, j, y}$ is the number of fish of age $i$ caught by gear $j$ in the year $y$ (for ANACO), $F_{i, y}$ is the fishing mortality for fish of age $i$ in the year $y$ and $C_{i, y}$ is the total number of fish of age $i$ caught in the year $y$.

VIT supplies some extra output in addition to those of a classic VPA. These results are interesting in that they provide information on the general condition of the studied stock and on its exploitation level. Among these items of information is the biomass balance which corresponds to the amount of biomass going in and out of the population during one year. The turnover is the proportion (expressed in percentage) between the biomass balance and the mean biomass. The ratio between the maximum biomass in the cohort 
Table 1. - Requirements and output for pseudo-cohort (VIT) and cohort (ANACO) virtual population analyses.

\title{
VIT
}

ANACO

\author{
Data Input \\ Catches/year/gear \\ Length or Age composition of catches (minimum 1 year) \\ Growth parameters (Von Bertalanffy's equation) \\ Length-Weight relationship \\ Natural mortality \\ Fishing terminal mortality (last age) \\ Maturity at age \\ VPA Output \\ Fishing mortality at age \\ Number of fish at age in the sea \\ Total biomass \\ Balance biomass \\ Turnover \\ Critical age and size
}

Catches/year/gear

Age composition of catches (several years without break)

Growth parameters (Von Bertalanffy's cquation)

Natural mortality

Fishing terminal mortality (last age)

Fishing terminal mortality (last year)

Maturity at age

Fishing mortality at age

Number of fish at age in the sea

Total biomass

Spawning stock biomass at critical age and the mean biomass is an expression of the dependence of the population either on a favourable issue or a total shortage in the annual recruitment. Critical age and critical size correspond to the class of the maximum biomass.

For the analysis of Yield-per-Recruit Y/R we used two outputs of another routine performed by VIT, the Y/R curve and the maximum sustainable yield MSY. For the estimation of $\mathrm{Y} / \mathrm{R}$, VIT uses the following equation derived from the catch equation by age, expressed in terms of the mean annual number of fish by age $i$ :

$$
\mathrm{Y} / \mathrm{R}=\frac{1}{N_{i}} \sum_{i=1}^{n} C_{i} \bar{u}_{i}=\frac{1}{N_{i}} \sum_{i=1}^{n} \bar{N}_{i} u_{i} F_{i}
$$

where $C_{i}$ is the number of fish caught at age $i$ and $\bar{w}_{i}$ the mean weight of fish at age $i$.

$C_{i}=F_{i} \cdot \bar{N}_{i}, \bar{N}_{i}$ being the mean annual number of fish at age $i$.

As in our prior studies, we have performed VPA on separate sexes with both computer programs but also on the total population (males + females) with ANACO. The analyses were carried out with VIT for each year and for a mean pseudocohort (years 1988 to 1991), in order to reduce the effect of initial variations in recruitment. This software was also used to estimate $\mathrm{Y} / \mathrm{R}$.

\section{Data input}

The annual weight of landings and the number of fish caught by age group are given for each type of gear (French trawl, Spanish trawl, gillnet and longline) and for the period 1988 to 1991 in appendix 1 . Catch statistics were compiled from various sources. For French trawl and gillnet the main sources are the French Fisheries Administration, fish auctions and fishermen, the later mainly for gillnet. Spanish Fishermen Associations provided the statistics for the Spanish trawl and longline catch.

The annual length frequency of landings results from a monthly sampling of the four gear, French trawl and gillnet sampling being carried out by the Sète IFREMER Fisheries laboratory, Spanish trawl and longline by Barcelona ICM Fisheries department. For the French trawl fleet, a stratified random sampling was carried out in fish auctions, while sampling was made directly on fishing boats for the three other gear. Sex demography was then obtained by applying a mean annual size-specific sex-ratio. This mean sex-ratio was estimated from data collected by sub-sampling the 4 gear catches in 1990-1991 according to a procedure covering the whole range of sizes. Age composition was obtained by the slicing method, a routine which is available in VIT. Total age composition was the simple sum of male and female numbers for each age group, which was carried out by ANACO. For females and total population, class 8 was the last age group used for VPA. In both cases this age group was a plus one. Only real age groups were used for males until age 9 which is the maximum age observed in landings for the studied period.

Data from specific sampling in commercial catches in the Gulf of Lions were analysed in the laboratory to calculate the biological parameters used in this study. These parameters are summarized in table 2.

Length/weight relationship: the same parameters were used in all cases because the differences between sexes were not significant $(p>0.05)$.

Growth: for the choice of the Von Bertalanffy's parameters, we took into account previous studies of the biology, sex-ratio according to size in landings (fig. 1) and growth of hake in the area as well as readings of daily increments of otoliths (Morales-Nin and Aldebert, 1994). The parameters used were those 
Table 2. - Biological parameters of $M$. merluccius in the Gulf of Lions.
Table 3. $-M$. merluccius. Terminal Fishing mortality. Initial values used for ANACO analyses (last year).

\begin{tabular}{|c|c|c|}
\hline & Females & Males \\
\hline \multicolumn{3}{|c|}{ Growth (von Bertalanffy's equation) } \\
\hline L inf. $(\mathrm{cm})$ & 100.7 & 72.8 \\
\hline k & 0.124 & 0.149 \\
\hline to & -0.350 & -0.383 \\
\hline \multicolumn{3}{|c|}{ Length/Weight relat. $\left(W_{(g)}=a \cdot L_{(\mathrm{rm})}^{b}\right)$} \\
\hline a & 0.0069 & 0.0069 \\
\hline b & 3.03 & 3.03 \\
\hline M & 0.18 & 0.22 \\
\hline \multicolumn{3}{|l|}{ Maturity at age } \\
\hline Age group 0 & 0 & 0) \\
\hline 1 & 0 & 0 \\
\hline 2 & 0 & 0.16 \\
\hline 3 & 0.28 & 0.86 \\
\hline 4 & 0.90 & 1 \\
\hline 5 and $>$ & 1 & 1 \\
\hline
\end{tabular}

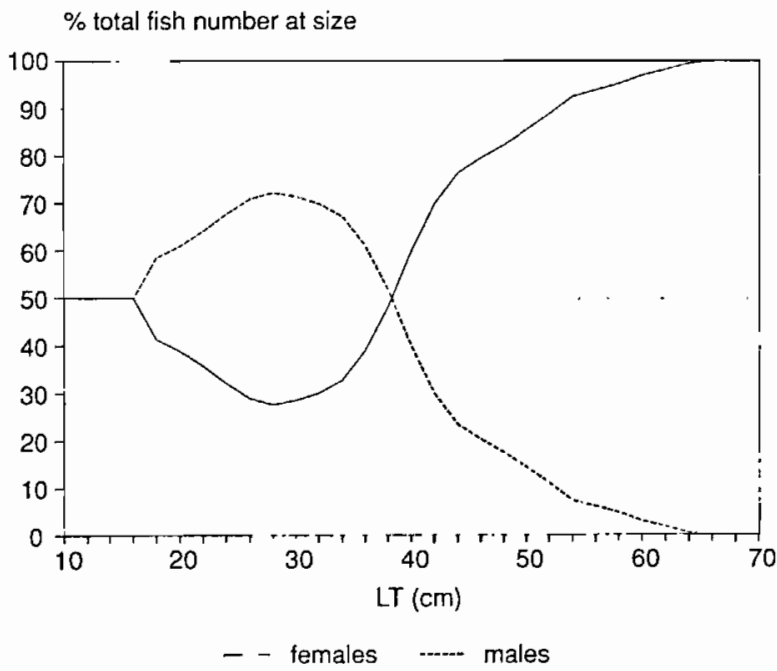

Figure 1. - Hake sex-ratio distribution (\%) according to length, in the Gulf of Iions.

calculated according to a method based on length frequency analysis (Aldebert and Recasens, 1995).

Natural mortality (M): due to the lack of accurate data on fishing effort, robust methods now available to estimate $M$ (Chen and Paloheimo, 1994) could not be used. The value retained was the mean of the calculations using the formulas of Taylor (1958) and Pauly (1980), but analyses with different values of $M$ (estimated value \pm 0.05 ) were performed to compare the sensitivity of the two methods to this parameter.

Maturity: data were obtained from observations made on both French and Spanish catches during the years 1990/1991. The length of fish at first maturity $\left(\mathrm{L}_{50}\right)$ was $40 \mathrm{~cm}$ for females and $28 \mathrm{~cm}$ for males.

Fishing mortality (F): preliminary analyses were carried out to test various values of $F_{\text {term }}$ (last age group) between 0.15 and 1.0 . The value 0.4 , which

\begin{tabular}{cccc}
\hline Age group & Females & Males & Total \\
\hline 0 & 0.25 & 0.15 & 0.20 \\
1 & 0.60 & 0.50 & 0.55 \\
2 & 0.50 & 0.70 & 0.60 \\
3 & 0.60 & 1.20 & 0.70 \\
4 & 0.85 & 1.40 & 0.90 \\
5 & 0.55 & 1.50 & 0.70 \\
6 & 0.40 & 1.40 & 0.50 \\
7 & 0.40 & 1.20 & 0.40 \\
8 & 0.40 & 0.50 & 0.40 \\
\hline
\end{tabular}

fit the best convergence, was retained as the most adequate for all the analyses. ANACO inputs required initial values of $F$ at age for the last year: the values chosen were those obtained performing VPA with VIT (table 3 ). Some complementary analyses were carried out for both sexes, using different values of $F$ for last year, in order to estimate the possible impact of that input: chosen initial $F_{\text {term }}$ at age $\pm 10 \%$ and a single value for all ages, equal to mean $F$ obtained from VIT results $\pm 10 \%$.

\section{RESULTS}

\section{Results of sensitivity analyses to $M$ and $F_{\text {term }}$}

\section{Natural mortality}

The values tested in the sensitivity analyses, initial value of $M \pm 0.05$, corresponded to very high variations of this parameter, i.e. +28 and $-38 \%$ for females, +23 and $-29 \%$ for males. The results of VPA performed with both softwares are summarized in table 4 . Performing ANACO for each value of $M$ parameter has an incidence of $\pm 3 \%$ and $\pm 5 \%$ on mean estimated fishing mortality and biomass respectively for females, of $\pm 2-3$ and $4-5 \%$ for males. With VIT, the incidence on mean estimated fishing mortality and biomass is slightly higher; variations of $\pm 7 \%$ and $\pm 8-9 \%$ were obtained for females, and of $\pm 2-3 \%$ and $\pm 5-6 \%$ for males. In every case, the ratio $\mathrm{F}_{\mathrm{VIr}} / \mathrm{F}_{\mathrm{ANACO}}$ or Biomass $_{\mathrm{VIT}} /$ Biomass $_{\mathrm{ANACO}}$ remain constant (maximum variation $1 \%$ ).

\section{Initial fishing mortality for last year (ANACO, VPA)}

Two series of analyses were carried out. For the first one, $10 \%$ variations of $\mathrm{F}_{\text {term }}$ at each age, according to results of VPA on mean pseudocohort performed with VIT, were used. Comparisons are made with reference values on mean fishing mortality rates and biomass for each year and for the mean of the 4 years (table 5). These comparisons show that both $\mathrm{F}$ and biomass are hardly influenced by changes of $10 \%$, with alterations of only $4-5 \%$ on the first year back calculated (1990), $2 \%$ for the previous year and no change for 1988. For the second series of analyses, performed on females, we input the same value of $F$ at all ages. $F$ values 
Table 4. - M. merluccius. Sensitivity of ANACO and VIT estimations to natural mortality variations (Biomass expressed in metric tons).

\begin{tabular}{|c|c|c|c|c|c|c|}
\hline \multirow[b]{2}{*}{$\begin{array}{l}M \text { input } \\
\text { values }\end{array}$} & \multicolumn{3}{|c|}{ Females } & \multicolumn{3}{|c|}{ Males } \\
\hline & $\begin{array}{c}\text { ref. }-0.05 \\
0.13\end{array}$ & $\begin{array}{l}5 \text { ref. } \\
0.18\end{array}$ & $\begin{array}{c}\text { ref. }+0.05 \\
0.23\end{array}$ & $\begin{array}{c}\text { ref. }-0.05 \\
0.17\end{array}$ & $\begin{array}{l}5 \text { ref. r } \\
0.22\end{array}$ & $\begin{array}{c}\text { ref. }+0.05 \\
0.27\end{array}$ \\
\hline $\begin{array}{l}\text { Mean F } \\
\text { (ANACO) }\end{array}$ & 0.519 & 0.502 & 0.485 & 0.913 & 0.894 & 0.869 \\
\hline $\begin{array}{l}\text { Mean Biomass } \\
\text { (ANACO) }\end{array}$ & 4048 & 4242 & 4452 & 2496 & 2605 & 2722 \\
\hline Mean F (VIT) & 0.599 & 0.556 & 0.515 & 1.018 & 0.981 & 0.945 \\
\hline $\begin{array}{l}\text { Mean Biomass } \\
\text { (VIT) }\end{array}$ & 3506 & 3789 & 4115 & 2294 & 2417 & 2554 \\
\hline
\end{tabular}

Table 5. $-M$. merluccius. Sensitivity of VPA to initial fishing mortality input (Estimations from ANACO).

\begin{tabular}{|c|c|c|c|c|c|c|}
\hline \multirow[b]{2}{*}{$\begin{array}{l}\text { Fterm at age } \\
\text { (last year) }\end{array}$} & \multicolumn{3}{|c|}{ Females } & \multicolumn{3}{|c|}{ Males } \\
\hline & $\begin{array}{l}\text { ref. } \\
\text { (VIT) }\end{array}$ & $\begin{array}{l}\text { ref. } \\
-10 \%\end{array}$ & $\begin{array}{l}\text { ref. } \\
+10 \%\end{array}$ & $\begin{array}{l}\text { ref. } \\
\text { (VIT) }\end{array}$ & $\begin{array}{l}\text { ref. } \\
-10 \%\end{array}$ & $\begin{array}{l}\text { ref. } \\
+10 \%\end{array}$ \\
\hline \multicolumn{7}{|c|}{$\begin{array}{l}\text { Mean fishing mortality } \\
\text { Mean }\end{array}$} \\
\hline 1988-1991 & 0.502 & 0.483 & 0.520 & 0.854 & 0.810 & 0.871 \\
\hline 1988 & 0.574 & 0.569 & 0.578 & 0.804 & 0.799 & 0.804 \\
\hline 1989 & 0.543 & 0.530 & 0.550 & 1.035 & 1.019 & 1.037 \\
\hline 1990 & 0.386 & 0.370 & 0.401 & 0.673 & 0.640 & 0.678 \\
\hline 1991 & 0.506 & 0.464 & 0.547 & 0.905 & 0.784 & 0.966 \\
\hline \multicolumn{7}{|c|}{$\begin{array}{l}\text { Mean biomass (metric tons) } \\
\text { Mean }\end{array}$} \\
\hline 1988-1991 & 4242 & 4424 & 4094 & 2605 & 2780 & 2527 \\
\hline 1988 & 3917 & 3950 & 3890 & 2336 & 2358 & 2329 \\
\hline 1989 & 3694 & 3778 & 3626 & 2269 & 2321 & 2241 \\
\hline 1990 & 3992 & 4186 & 3834 & 2451 & 2571 & 2371 \\
\hline 1991 & 5366 & 5784 & 5026 & 3363 & 3629 & 3163 \\
\hline
\end{tabular}

retained were the mean $F$ resulting from VIT VPA, $\mathrm{F}=0.506, \pm 10 \%$ i.e. 0.455 and 0.557 . Convergence of fishing mortality for all ages with reference values is rather quick as can be seen from figure 2, the overlapping being nearly complete for 1988 .

\section{Virtual Population Analysis results common to VIT and ANACO}

The main results of the VPA performed with VIT and ANACO are presented in the same way in table 6, in order to make their comparison easier. In addition, the results given by the ANACO analyses concern mean values (year 1988 to year 1991) for the numbers of fish. Biomass corresponds to its initial value at the beginning of the season. It was recalculated using mean weight at age for VIT results, whose standard output is the mean biomass in the stock.

The age-specific fishing mortality curve shows a rather good convergence of the two methods for both sexes ( fig. 3). F rates can be considered as reliable up to age 6 for both methods. Actually a good convergence could be observed until this age in preliminary tests varying $F_{\text {term }}$ at last age. The fishing
Table 6. $-M$. merluccius, Main results of VPA based on pscudocohorts (VIT) and on cohorts (ANACO).

\begin{tabular}{|c|c|c|c|c|c|}
\hline \multirow[b]{3}{*}{ Agc group } & \multicolumn{5}{|c|}{ Numbers at sea (thousands) } \\
\hline & \multicolumn{2}{|c|}{ VIT } & \multicolumn{2}{|c|}{ ANACO } & \multirow[b]{2}{*}{ Total } \\
\hline & Females & Males & Females & Males & \\
\hline 0 & 14187 & 20115 & 21057 & 24982 & 46217 \\
\hline 1 & 9003 & 13885 & 11729 & 15500 & 27647 \\
\hline 2 & 4079 & 6586 & 4577 & 6667 & 11723 \\
\hline 3 & 2051 & 2622 & 2126 & 2512 & 5026 \\
\hline 4 & 919 & 617 & 899 & 769 & 1757 \\
\hline 5 & 315 & 118 & 317 & 188 & 533 \\
\hline 6 & 143 & 20 & 156 & 33 & 199 \\
\hline 7 & 71 & 4 & 87 & 7 & 101 \\
\hline \multirow[t]{2}{*}{8} & 34 & 1 & 72 & 2 & 75 \\
\hline & \multicolumn{5}{|c|}{ Biomass (tons) } \\
\hline \multicolumn{6}{|l|}{ Year } \\
\hline 1988 & 3972 & 2397 & 3917 & 2336 & 6269 \\
\hline 1989 & 3586 & 2421 & 3694 & 2269 & 6041 \\
\hline 1990 & 2685 & 1598 & 3992 & 2451 & 6619 \\
\hline 1991 & 4582 & 3335 & 5366 & 3363 & 9017 \\
\hline mean $88 / 91$ & 3789 & 2418 & 4242 & 2604 & 6987 \\
\hline
\end{tabular}

Table 7. $-M$. merluccius. Specific results of VPA based on pseudocohorts (estimations from VIT).

\begin{tabular}{lcc}
\hline & Females & Males \\
\hline Mean biomass (tons) & 2714 & 1500 \\
Balance biomass (tons) & 2116 & 1544 \\
Turnover (\%) & 78 & 103 \\
Max. biomass/mean biomass (\%) & 23.2 & 34.2 \\
Critical age (years) & 3 & 2 \\
Critical length (cm) & 34.2 & 21.8 \\
\hline
\end{tabular}

mortality at age, total and for each type of gear are illustrated in figure 4 for VPA performed on male and female populations separately and in figure 5 for the total population. The shape of the curves differs between males and females. Variations of the sexratio according to the size, with a majority of males for small fish and of females for large ones, as well as the great difference in the growth rate of males and females may explain these divergences. The fishing mortality curve of the total population became quite similar to that of the females as age increased due to the predominance of this sex in catches when age reaches five years or more.

The two trawler fleets exploit all age groups of the hake stock but mainly the youngest ones. Their rate of exploitation is different and correlated rather directly to the number of boats: the greater part of fishing mortality is due to the French trawlers which are much more numerous than the Spanish ones (Aldebert et al., 1993). A first relative peak can be observed on the $F$ curve at age one; it corresponds to the size at which young hakes are fully exploited by trawlers. Gillnets and longlines catch fish from age three but mainly 4 or 5-year-old adults. This explains the second, higher 


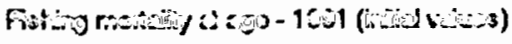

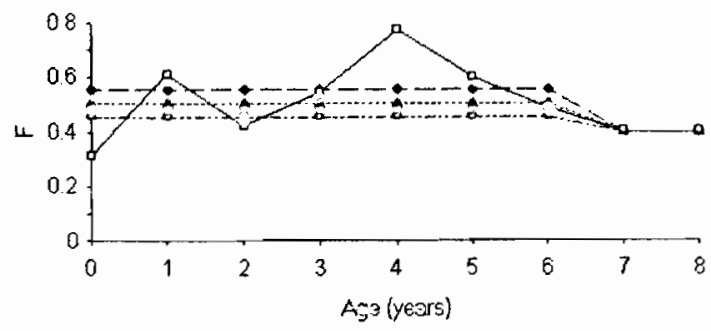

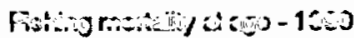

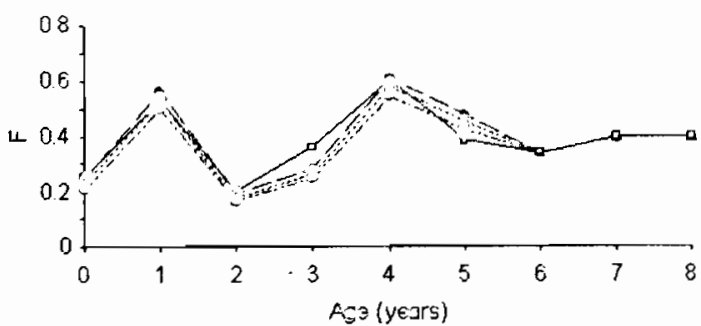

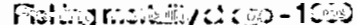

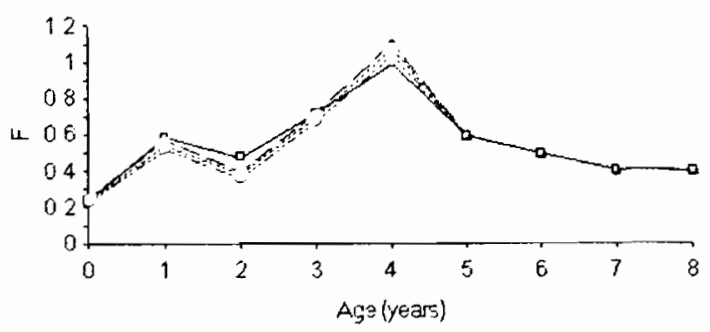

Fingoratiogas -100

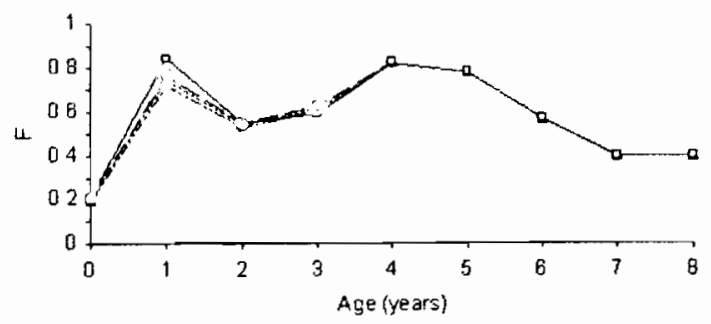

F ref $\longrightarrow F=0455 \ldots F=0506 \cdots \quad F=0557 \ldots$

Fizure 2. - Sensitivity of VPA to $F_{\text {term }}$ input for last year. Fishing mortality of hake (females) in the Gulf of Lions (F ref: VIT estimations).
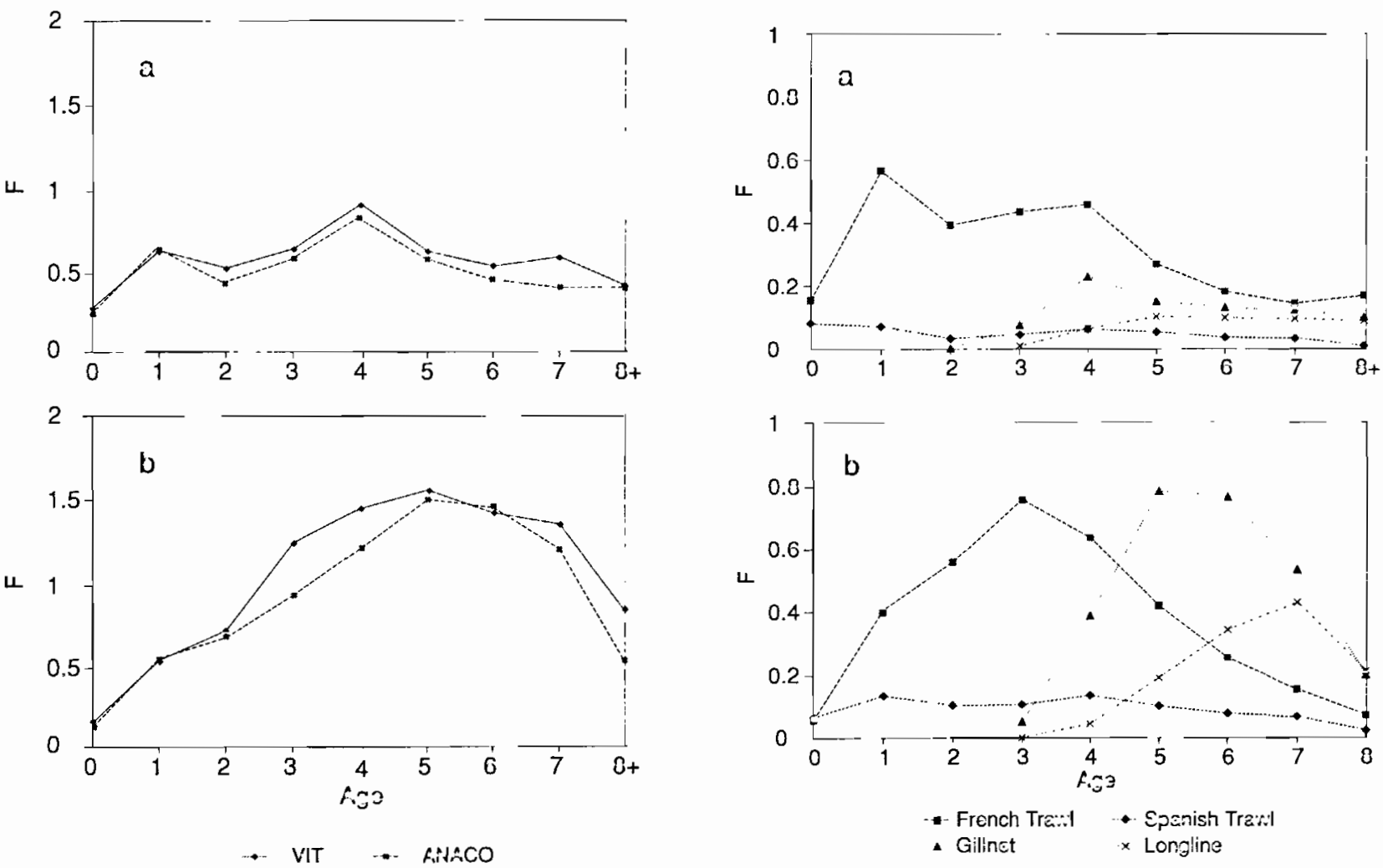

Figure 3. - Hake total fishing mortality at age, mean 1988-1991. a: females, b: males.

Fizure 4. - Hake fishing mortality at age for each type of gear (estimations from ANACO), mean 1988-1991. a: females, b: males. 


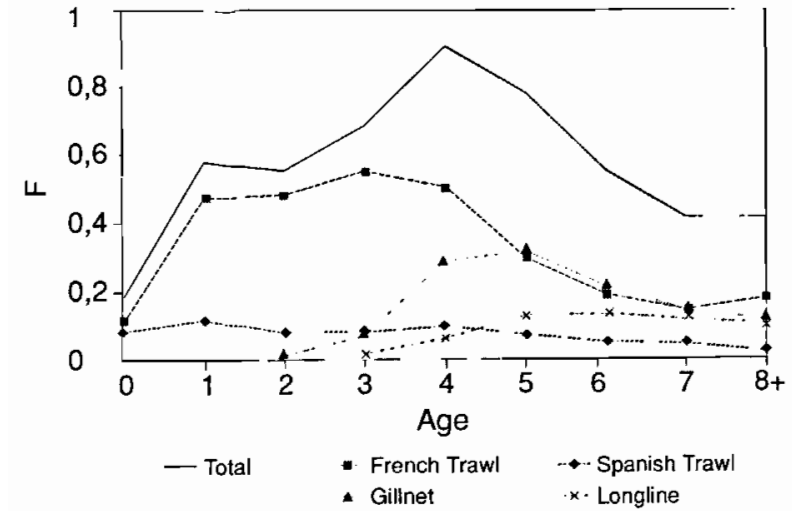

Figure 5. - Hake fishing mortality at age for each type of gear (results of ANACO), mean 1988-1991. Total population (females + males).

peak of the F curve, corresponding to the age at which hake stock is exploited by all types of gear.

\section{Results specific to each method}

The results of the additional output of VIT are interesting as they provide information on the general condition of hake stock and on its exploitation level. In the present study, the balance biomass and turnover (table 7), which both correspond to the renewal rates, were very high, specially for males, this being an expression of the heavy degree of exploitation of hake in the Gulf of Lions. In the same way, the critical age and size differ strongly from mean age and size in catches; their values were higher for females than for males due to the difference of growth rates in the two sexes.

The results of the $Y / R$ analysis (table 8, fig. 6) showed that the present rate of exploitation (equal to 1) is beyond the optimal biological yield for both males and females, with higher values of $Y / R$ for the latter. When considering the allocation of $Y / R$ for each type of gear, it is obvious that the French trawler fleet gets the larger part of it while small-scale fishery gear (gillnet and longline) can get only a very small proportion especially for the male population.

ANACO does not permit the calculation of these parameters. Among the VPA results, ANACO gives an estimation of the spawning stock biomass (SSB), in addition to the total stock biomass (TSB). Since four years is a short period, the ratio SSB/TSB shows annual variations between 45 and $35 \%$ both for males and females, with a possible decrease from 1988 (table 9).

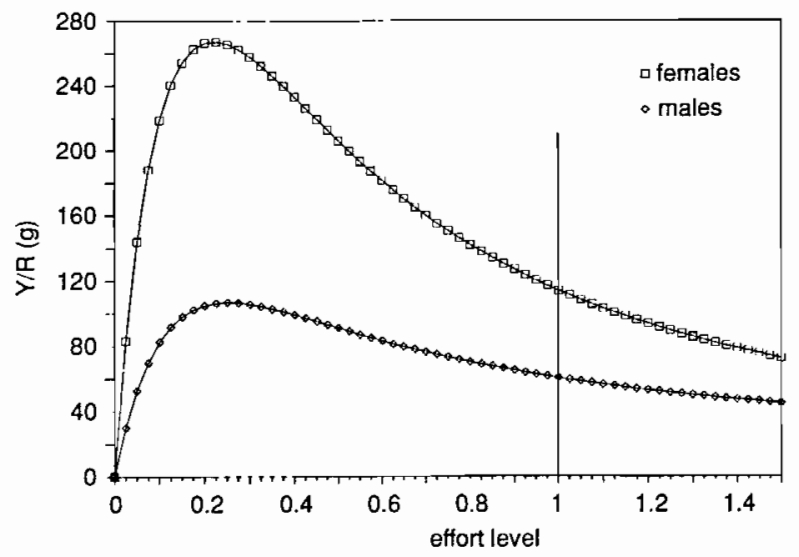

Figure 6. - Hake Yield-per-Recruit analysis (results of VIT).

Table 9. - Hake Spawning Stock Biomass (SSB) in the Gulf of Lions and proportion in the total stock biomass (estimations from ANACO).

\begin{tabular}{lccccc}
\hline Yaer & 1988 & 1989 & 1990 & 1991 & mean \\
\hline Females & & & & & \\
SSB (tons) & 1788 & 1628 & 1490 & 1954 & 1715 \\
SSB/Biomass (\%) & 45.6 & 44.1 & 37.3 & 36.4 & 40.4 \\
Males & & & & & \\
SSB (tons) & 1033 & 991 & 870 & 1433 & 1082 \\
SSB/Biomass (\%) & 44.2 & 43.7 & 35.5 & 42.6 & 41.5 \\
Total & & & & & \\
SSB (tons) & 3036 & 2777 & 2617 & 3993 & 3106 \\
SSB/Biomass (\%) & 48.4 & 46.0 & 39.5 & 44.3 & 44.5 \\
\hline
\end{tabular}

\section{DISCUSSION AND CONCLUSION}

Before undertaking the comparison of the two methods, a main point to clarify was the impact of last year $F_{\text {term }}$ input for ANACO estimations, since only 4 years' data were available. The trials carried out where this parameter is varied agree to show a rather quick convergence of back-calculated Fs when performing the VPA. Introducing as $F_{\text {term }}$ values for the last year Fs obtained from VIT analysis should not have serious consequences on ANACO results. Concerning the uncertainty on natural mortality, the results of the VPA performed with both programs using different values for $M$ showed that estimated Fishing mortality and biomass vary in the same way within a similar range. Of course, the input values for $F_{\text {term }}$ and $M$ as well as growth parameters have a direct impact on absolute Fishing mortalities and biomass estimated

Table 8. - Hake Yield-per-Recruit (Y/R) estimations from VIT. FT = French trawl, ST = Spanish trawl, GN = gillnet, LL=longline.

\begin{tabular}{|c|c|c|c|c|c|c|c|c|c|c|}
\hline & \multicolumn{5}{|c|}{ Females } & \multicolumn{5}{|c|}{ Males } \\
\hline Y/R present level $(\mathrm{g})$ & 114.8 & 74.9 & 10.4 & 22.5 & 7.0 & 60.4 & 48.0 & 9.2 & 2.1 & 1.1 \\
\hline
\end{tabular}


from VPA. This impact was shown by sensitivity analyses performed in previous studies on hake stock in the Gulf of Lions (Aldebert and Carries, 1991; Recasens, 1992a). However, the present results allow us to undertake an analysis and a comparison of the two methods of performing VPA, given the available data base.

The VIT program, as well as other methods of VPA based on pscudocohorts analysis, is based on the assumption of the equilibrium of the stock and its exploitation and the constancy of the annual recruitment. During the period 1988-1991, the conditions of exploitation of hake stock in the Gulf of Lions remained quite steady. However, large fluctuations in recruitment were observed with a very high peak and large landings of 0 group fish in 1991 (appendix 1). As pointed out by Pallares (1992), the use of mean pseudocohorts, based on four years' data in the present study, can compensate for this variability. For the French hake fishery in the Gulf of Lions, mean length pseudocohorts had already been used in previous studies (Aldebert and Carries, 1988, 1991).

For the ANACO program, the initial values of $F$ assigned for the last year compensated for the short period for which data are available. Furthermore, one can find in the literature papers relative to various species of Merluccius, in which VPA was carried out in similar conditions (Lleonart et al., 1985; Recasens, 1992a). Also, the specific pattern of exploitation of hake in the Gulf of Lions, characterized by high catches of juveniles belonging to age groups 0 to 2 , well covered with four data years, may be an element of justification.

Rather similar results were obtained for population analyses based on both pseudocohorts and on cohorts with regard to fishing mortality vectors up to the age of six years. The small differences observed for the first years may be due to the fact that VIT results were based on a mean pseudocohort whereas those given for ANACO correspond to the mean of four years of results. This explanation could also apply to the numbers of fish. The ANACO program gives the same mortality value to the penultimate as to the last age groups.

The results of VPA carried out separately on male and female cohorts showed obvious differences concerning estimated biomass as well as mortality curves by sex.
Thus, for species whose growth rate differs according to sex, it seems necessary to take this into account but this can be done either when compiling the demography of catches or later on when performing the VPA. Indeed, the total biomass of hake estimated for the Gulf of Lions is $6987 \mathrm{t}$ when analysing the total population, and $6846 \mathrm{t}$ when adding male and female biomass estimated separately. The difference is only about $2 \%$, which is low in comparison to other possible biases.

From a methodological point of view, the overall results of this study seem to validate methods of population analysis based on mean pseudocohorts in cases where only a correct estimation of the mean state of stock is needed.

The stock of hake in the Gulf of Lions was estimated to have an average biomass of $7000 \mathrm{t}$, of which $45 \%$ corresponded to adults, with yearly variations between 6000 and 9000 t during the period 1988-1991.

As the analysis of pseudocohorts showed, there is a considerable renewal of annual biomass, expressed by the high level of turnover, especially in the male population. On the other hand, the dependence of the hake stock with regard to recruitment remains limited, unlike some cases encountered for short-lived demersal species. The turnover and the maximum biomass/mean biomass ratio always reached higher values for males than for females, thus expressing the higher mortality rate of the former. The values of 23 and 34 observed for this ratio are relatively low when compared to the results of other studies giving values reaching 40\% (Ramon, 1993). They are equivalent to those observed recently for other demersal species in the Gulf of Lions (Farrugio et al., 1994). Thus, one may assume that, in spite of a high level of exploitation, the population of hake of the Gulf of Lions is not too highly dependent on annual recruitment taking into account that hake is a rather long-living species.

Concerning yield-per-recruit, the results of the present study confirm those obtained in previous stock assessments of Mediterranean hake in the Gulf of Lions (Aldebert and Carries, 1990), in the Catalan Sea (Recasens, 1992) and in the Balearic area (Oliver, 1992): the present level of fishing effort is well beyond the biological optimal level of exploitation. However, the stock level of hake in the Gulf of Lions does not seem to be so low as to be in danger of collapsing.

\section{Acknowledgements}

This work has been made possible by the financial support of the FAR European Community research programme "Study for assessment and management of fisheries in the Western Mediterranean". We are grateful to the persons who have collaborated to this programme, especially to Jordi Lleonart and Claude Carries for their help, and to Dr Y. Chen for his valuable comments and critics of the manuscript. 


\section{REFERENCES}

Aldebert Y., C. Carriès 1988. Problèmes d'exploitation du merlu dans le golfe du Lion. FAO Rapp. Pêches 395, 87-91.

Aldebert Y., C. Carriès 1990. L'exploitation du merlu dans le golfe du Lion. Données complémentaires. Bull. Soc. Zool. France 114, 15-20.

Aldebert Y., C. Carriès 1991. Application de l'analyse des populations virtuelles au stock de merlu du golfe du Lion. Impact de modifications des régimes d'exploitation. FAO Rapp. Pêches 447, 143-150.

Aldebert Y., L. Recasens 1995. Estimation de la croissance du merlu dans le golfe du Lion par l'analyse des fréquences de tailles. Rapp. Comm. int. Mer Médit. 34, 236.

Aldebert Y., L. Recasens, J. Lleonart 1993. Analysis of gear interactions in a hake fishery: the case of the gulf of Lions (NW Mediterranean). Sci. Mar. 57, 207-217.

Chen Y., J. E. Paloheimo 1994. Robust regression approach to estimating fish mortality rates with a cohort-based model. Trans. Am. Fish. Soc. 123, 508-518.

Demestre M., J. Lleonart 1993. Population dynamics of Aristeus antennatus (Decapoda : Dendrobranchiata). Sci. Mar. 57, 183-189.

Farrugio H., G. Le Corre, G. Vaudo 1994. Population dynamics of sea bass, sea bream and sole exploited by the French multigears demersal fishery in the Gulf of Lions (Northwestern Mediterranean). In: Study for assessment and management of fisheries in the Western Mediterranean (part 2), Contract CEE/FAR MA 3-621, 150-167.

Gulland J. A. 1983. Fish stock assessment. A manual of basic methods. FAO/Wiley Ser. on Food and Agriculture $1,223$.

Lleonart J., J. Salat 1992. VIT, un programa para análisis de pesquerías. Inf. Técn. Sci. Mar. 168-169, 116 p.

Lleonart J., J. Salat, E. MacPherson 1985. Un MSVPA (Multispecies Virtual Population analysis) empirico. Aplicación a la merluza del Cabo, considerando el canibalismo y la depredación de la rosada. Simp. Int. Atl. Q. Afr. Inst. Inv. Pesq. Barcelona II, 1041-1052.
Mesnil B. 1989. Computer programs for fish stock assessment. ANACO: Software for the analysis of catch data by age group on IBM-PC and compatibles. FAO Fish. Tech. Pap. 101 (Suppl. 3), 73 p.

Morales-Nin B., Y. Aldebert 1994. Growth and hatchdate distribution of juvenile Merluccius merluccius in the Gulf of Lions (NW Mediterranean) determined by otolith microstructure and length frequency distribution. In : Study for assessment and management of fisheries in the Western Mediterranean (part 2), Farrugio et al. Contract CEE/FAR MA 3-621, 56-67.

Oliver P. A. 1992. Dinámica de la población de Merluza (Merluccius merluccius L.) de Mallorca. Reclutamiento, crecimiento y mortalidad. Ph.D. Thesis, Univ. Baleares, 392 p.

Oliver P. A. 1993. Analysis of the fluctuations observed in the trawl fleet landings of the Balearic Islands. Sci. Mar. 57, 219-227.

Pallares P. 1992. Comparación de los resultados de la aplicació de técnicas de análisis de población virtual sobre distribuciones de edad y distribuciones de tallas con aplicaciones a la evaluación de stocks explotados de diferentes grupos taxonómicos. Ph.D. Thesis, Univ. Complutense Madrid, 173 p.

Pauly D. 1980. On the interrelationships between natural mortality growth parameters and mean environmental temperature in 175 fish stocks. J. Cons. Int. Explor. Mer 39, 175-192.

Ramon M. 1993. Estudio de las poblaciones de Chamelea gallina y Donax trunculus en el golfo de Valencia. Ph.D. Thesis, Univ. Barcelona, 413 p.

Recasens L. 1992a. Dinámica de poblaciones i pesqueria del Lluç (Merluccius merluccius) al golf de Lleó i la mar Catalana. Ph.D. Thesis, Univ. Barcelona, 398 p.

Recasens L. 1992 $b$. L'état d'exploitation du merlu (Merluccius merluccius) de la mer Catalane (Nord-Ouest Méditerranée). Rapp. Comm. int. Mer Médit. 33, 309.

Taylor C. 1958. Natural mortality rate of Georges Bank haddock. U.S. Fish. Wildl. Serv. Fish. Bull. 58, 1-7. 
Afrersix 1. - Landings of European hake Merluccius merluccius per sex and gear in the Gulf of Lions. Quantities (metric tons, $t$ ) and number of fish caught.

\begin{tabular}{|c|c|c|c|c|c|c|c|c|c|}
\hline \multirow[b]{2}{*}{ Year } & \multirow[b]{2}{*}{ Age group } & \multicolumn{2}{|c|}{ French trawl } & \multicolumn{2}{|c|}{ Spanish trawl } & \multicolumn{2}{|c|}{ gillnet } & \multicolumn{2}{|c|}{ longline } \\
\hline & & Females & Males & Females & Males & Females & Males & Females & Males \\
\hline \multirow{8}{*}{1988} & 0 & 1291.9 & 4() 4.4 & 996.9 & 1064.8 & () & 0 & () & () \\
\hline & 1 & 4286.6 & 3749.3 & 577.3 & 1370.4 & 0 & 0 & 0 & 0) \\
\hline & 2 & 1298.8 & 2780.9 & 115.4 & 552.6 & 10.2 & 1.1 & 0.1 & () \\
\hline & 3 & $6,00.4$ & 983.7 & 87.8 & 154.8 & 130.2 & 76.9 & 8.0 & 1.9 \\
\hline & 6 & 33.5 & 3.3 & 6.8 & 1.6 & 16.6 & 9.9 & 17.1 & 6.4 \\
\hline & 7 & 10.0 & 0.6 & 2.0 & 0.3 & 8.9 & 1.5 & 11.1 & 2.4 \\
\hline & $8+$ & 3.5 & 0.2 & 0.3 & 0.1 & 6.9 & 0.4 & 11.5 & 0.5 \\
\hline & Landings (t) & 1162.7 & 850.4 & 183.3 & 197.8 & 246.2 & 138.3 & 139.7 & 22.4 \\
\hline \multirow{6}{*}{1989} & \multicolumn{9}{|c|}{ Numbers (thousands) } \\
\hline & 5 & 48.1 & 40.7 & 15.9 & 15.6 & 68.7 & 84.9 & 29.4 & 27.1 \\
\hline & 6 & 17.2 & 4.5 & 3.9 & 2.6 & 13.7 & 19.3 & 11.0 & 8.1 \\
\hline & 7 & 10.3 & 0.5 & 2.3 & 0.55 & 7.5 & 2.8 & 6.2 & 2.0 \\
\hline & $8+$ & 6.8 & 0.1 & 1.1 & 0.07 & 7.5 & 0.47 & 3.4 & 0.35 \\
\hline & Landings (t) & 1090.3 & 812.3 & 118.5 & 167.2 & 244.6 & 142.9 & 121.1 & 34.9 \\
\hline \multirow{7}{*}{1990} & \multicolumn{9}{|c|}{ Numbers (thousands) } \\
\hline & 0 & 2820.6 & 1156.6 & 1600.3 & 1227.6 & 0 & 0 & 0 & 0 \\
\hline & 1 & 4425.8 & 4897.9 & 815.4 & 1803.9 & 0 & 0 & 0 & 0 \\
\hline & 2 & 595.7 & 1529.4 & 93.1 & 247.5 & 15.6 & 2 & 0 & 0 \\
\hline & 3 & 354.8 & 509.3 & 53.9 & 112.7 & 106.3 & 102.4 & 6.4 & 0.4 \\
\hline & 4 & 146.8 & 143.1 & 25.3 & 31.5 & 105.8 & 125.8 & 23.8 & 11.1 \\
\hline & 5 & 33.8 & 21.8 & 6.2 & 4.6 & 25.3 & 48.8 & 19.1 & 10.9 \\
\hline \multirow{7}{*}{1991} & 3 & 1008.9 & 2102.8 & 53.3 & 181.1 & 116.4 & 63.8 & 22.6 & 1.6 \\
\hline & 4 & 388.6 & 414.9 & 11.8 & 34.3 & 146.2 & 180.6 & 29.0 & 22.2 \\
\hline & 5 & 74.3 & 54.3 & 3.9 & 2.6 & 35.7 & 86.2 & 13.9 & 13.9 \\
\hline & 6 & 23.3 & 6.2 & 1.1 & 0.3 & 16.6 & 13.9 & 7.7 & 2.6 \\
\hline & 7 & 13.5 & 0.7 & 0 & 0.1 & 8.7 & 2 & 4.4 & 0.5 \\
\hline & $8+$ & 12.9 & 0.1 & 0.3 & 0 & 4.6 & 0.4 & 3.3 & 0.1 \\
\hline & Landings $(\mathrm{t})$ & 1684.6 & 1300.4 & 158.6 & 220.6 & 249.0 & 147.3 & 75.3 & 19.5 \\
\hline \multirow{11}{*}{$\begin{array}{l}\text { Mean } \\
88-91\end{array}$} & \multicolumn{9}{|c|}{ Numbers (thousands) } \\
\hline & 0 & 2713.7 & 1258.5 & 1419.0 & 1395.8 & 0 & () & 0 & 0 \\
\hline & 1 & 4310.6 & 4327.8 & 600.0 & 1448.9 & 0 & 0 & 0 & 0 \\
\hline & 2 & 1338.3 & 2423.7 & 118.5 & 442.5 & 9.2 & 1.2 & 0.1 & 0 \\
\hline & 3 & 655.2 & 1163.0 & 65.0 & 152.7 & 109.8 & 73.4 & 14.4 & 1.4 \\
\hline & 4 & 266.5 & 262.5 & 34.0 & 52.5 & 130.5 & 158.5 & 35.7 & 17.8 \\
\hline & 5 & 60.0 & 38.1 & 11.6 & 8.8 & 41.2 & 70.2 & 22.9 & 16.6 \\
\hline & 6 & 21.3 & 4.1 & 4.1 & 1.3 & 15.2 & 12.5 & 11.4 & 5.5 \\
\hline & 7 & 9.7 & 0.5 & 2.1 & 0.3 & 8.0 & 1.8 & 6.5 & 1.6 \\
\hline & $8+$ & 9.6 & 0.1 & 0.5 & 0.0 & 5.9 & 0.4 & 5.3 & 0.3 \\
\hline & Landings $(t)$ & 1179.1 & 883.5 & 151.4 & 183.7 & 234.8 & 134.3 & 102.0 & 23.3 \\
\hline
\end{tabular}

